\title{
ESTADO ACTUAL DE LA JURISPRUDENCIA EN MATERIA DE ACUMULACIÓN DE PORCENTAJES DE PÉRDIDA DE CAPACIDAD LABORAL DE DISTINTOS ORÍGENES EN EL ASEGURAMIENTO DEL RIESGO DE INVALIDEZ*
}

\section{CURRENT STATUS OF COLOMBIAN JURISPRUDENCE ON THE INSURANCE OF DISABILITIY RISK GENERATED BY THE ACCUMULATION OF LABOR CAPACITY LOSS PERCENTAGES FROM DIFFERENT ORIGINS}

\author{
Carolina Gómez González** \\ Néstor Alejandro García Franco*** \\ Fecha de recepción: 30 de junio de 2016 \\ Fecha de Aceptación: 15 de julio de 2016 \\ Disponible en línea: 30 de Julio de 2016
}

\section{Para Citar este articulo/To cite this article}

Gómez González, Carolina \& García Franco, Néstor Alejandro, Estado actual e la Jurisprudencia en Materia de acumulación de porcentajes de pérdida de capacidad laboral de distintos orígenes en el aseguramiento del riesgo de invalidez, 44 Rev.Ibero-Latinoam.Seguros, 233-268 (2016). http://dx.doi.org/10.11144/Javeriana.ris44.eajm

doi:10.11144/Javeriana.ris44.eajm

\footnotetext{
* Trabajo de investigación para optar al título de especialista en derecho seguros de la Pontificia Universidad Javeriana.

** Abogada de la Universidad Libre Seccional Pereira, especialista en Responsabilidad y Daño Resarcible de la Universidad Externado, especialista en Derecho de Seguros de la Pontificia Universidad Javeriana, Máster en derecho de daños de la Universidad de Girona en España, actualmente se desempeña como Directora Nacional de Procesos Judiciales de Suramericana para Colombia. Contacto: cgomezg@sura.com.co

*** Abogado egresado de la Universidad La Gran Colombia Seccional Armenia, especializado en Derecho Procesal de la Universidad del Rosario y en Derecho de Seguros de la Pontificia Universidad Javeriana. Fundador y líder de GARCÍA FRANCO ABOGADOS RC. Y SEGUROS, Es miembro del Instituto de Responsabilidad Civil y del Estado - Eje Cafetero y de la Asociación Colombiana de Derecho de Seguros - ACOLDESE- Capítulo Pereira. Expositor en diversos foros en temas de responsabilidad civil y del Estado y del Sistema General de Riesgos Laborales. Contacto: nestoralejandrogarciafranco@gmail.com
} 


\section{RESUMEN}

El aseguramiento del riesgo de invalidez en el Sistema de Seguridad Social en Colombia, se encuentra a cargo de los subsistemas de pensiones y riesgos laborales, en los que se encuentra contemplada, como prestación económica que pretende indemnizar tal riesgo, la pensión de invalidez.

Dicha pensión de invalidez es asumida en el sistema general de pensiones por las Administradoras de Fondos de Pensiones y en el sistema general de riesgos laborales por las Administradoras de Riesgos Laborales, correspondiendo a las primeras asumir el pago de la mencionada prestación a los afiliados que se invaliden como consecuencia de un riesgo común, mientras que a las segundas corresponde el pago de las pensiones que se generen por la concreción de un riesgo laboral. En ocasiones un afiliado al sistema puede presentar un porcentaje de pérdida de capacidad laboral de origen común y al mismo tiempo otro porcentaje de origen laboral, que tomados individualmente no permiten al afiliado obtener una prestación económica, pero que sumados uno y otro, le otorgan la condición de inválido.

En virtud de los efectos de la sentencia C-425 de 2005 de la Corte Constitucional, en casos como el anteriormente descrito, la jurisprudencia colombiana ha obligado bien a una AFP o bien a una ARL a asumir el pago de la totalidad de la pensión de invalidez, situación que puede constituir un exceso en la carga obligacional que cada una de estas entidades ha asumido en virtud del aseguramiento del respectivo riesgo.

Palabras claves: Sistema de seguridad social; sistema general de riesgos laborales; sistema general de pensiones; pensión de invalidez; pérdida de capacidad laboral; origen común; origen laboral. 


\section{ABSTRACT}

The insurance of the risk of disability in the Social Security System in Colombia, is in charge of the subsystems in pensions and occupational hazards. Those subsystems include the disability pension which is a benefit that aims to compensate such a risk.

The disability pension is assumed in the pensions system by the managers of pension funds (AFP) and in the system of occupational hazards by the managers of those risks (ARL), corresponding to the first to assume the payment of the mentioned provision to members who are disabled as a result of a common risk, while the latter corresponds to the payment of pensions that are generated by the happening of an occupational hazard.

Occasionally an affiliated of the system may present a percentage of loss of labor capacity from a common origin, and at the same time another percentage caused by work, each one of those situations taken individually may not allow the affiliated to obtain a disability pension, but adding one to another, they give the invalid condition and the right to obtain that pension.

Under the effects of the judgment C-425 in 2005 of the Constitutional Court, in cases such as the above, Colombian jurisprudence has well forced to an AFP or to an ARL to assume the payment of the totality of the disability pension, which may constitute an excess in the obligational burden that each of these entities has assumed under the respective assurance of the risk.

Key words: Social security system; occupational hazards system; pensions system; disability pension; percentage of loss of labor capacity; common origin; occupational origin.

\section{SUMARIO}

INTRODUCCIÓN. 1. ESTADO ACTUAL DE LA JURISPRUDENCIA COLOMBIANA FRENTE A LA ACUMULACIÓN DE PORCENTAJES DE PCLDE DISTINTOS ORÍGENES. 1.1. EL ASEGURAMIENTO DEL RIESGO DE INVALIDEZ EN EL SISTEMA INTEGRAL DE SEGURIDAD SOCIAL EN COLOMBIA. 1..1.1. El aseguramiento del riesgo de invalidez en el sistema general de pensiones. 1.1.2. El aseguramiento del riesgo de invalidez en el sistema general de riesgos laborales. 1.1.3. Diferencias en el aseguramiento del riesgo de invalidez en el sistema general de pensiones y en el sistema general de riesgos laborales. 1.1.4. La calificación de la pérdida de capacidad laboral en el sistema integral de seguridad social 2. LÍNEA JURISPRUDENCIAL SEGUIDA POR LA CORTE CONSTITUCIONAL Y LA SALA LABORAL DE LA CORTE SUPREMA DE JUSTICIA A PARTIR DE LA SENTENCIA C-425 DE 2005. CONCLUSIONES. REFERENCIAS BIBLIOGRÁFICAS. 


\section{INTRODUCCIÓN}

El propósito de la presente reseña jurisprudencial no es otro que explorar el estado actual de la jurisprudencia nacional en relación con la posibilidad de acumulación de porcentajes de pérdida de capacidad laboral de distintos orígenes en el aseguramiento del riesgo de invalidez, que incumbe tanto al Sistema General de Pensiones como al Sistema General de Riesgos Laborales.

El interés por esta materia surgió de los efectos que se observan en la práctica diaria del aseguramiento del riesgo de invalidez, derivados de la sentencia C-425 de 2005 de la Corte Constitucional, mediante la cual se declaró inexequible el parágrafo primero del artículo primero de la Ley 776 de 2002 que disponía: "La existencia de patologías anteriores no es causa para aumentar el grado de incapacidad, ni las prestaciones que correspondan al trabajador".

A partir de dicho fallo, la jurisprudencia nacional ha emitido una serie de sentencias regularmente consonantes, en las que resuelve casos concretos de afiliados al Sistema de Seguridad Social que se muestran materialmente inválidos como consecuencia de la sumatoria de porcentajes de pérdida de capacidad laboral de diversos orígenes, declarando responsable del pago de la prestación de pensión de invalidez a una sola entidad del sistema, bien sea una AFP o una ARL, generando un evidente desequilibrio en el contenido obligacional del respectivo asegurador del sistema, quien deberá asumir el pago de una prestación derivada, en parte, de un riesgo que no asumió, ni que estaba obligado a asumir contractual ni legalmente.

Se expondrá nuestra posición crítica frente a los fallos analizados, así como las conclusiones que genera el estudio del conflicto planteado, señalando de manera general unos posibles escenarios de solución del conflicto, no sólo desde el punto de vista del aseguramiento asumido, sino también del respeto por el debido proceso y derecho de contradicción de las entidades aseguradoras del sistema.

\section{ESTADO ACTUAL DE LA JURISPRUDENCIA COLOMBIANA FRENTE A LA ACUMULACIÓN DE PORCENTAJES DE PCL DE DISTINTOS ORÍGENES}

Nos proponemos indagar el estado actual de la jurisprudencia nacional, respecto de la posibilidad de acumular porcentajes de pérdida de ca- 
pacidad laboral de distintos orígenes, cuando concurren en una misma persona, y que le permiten acceder a una prestación económica precisa, como es una pensión de invalidez a cargo de una de las entidades aseguradoras del Sistema Integral de Seguridad Social, como pueden ser un Fondo de Pensiones o una Administradora de Riesgos Laborales, que en principio no hubiesen estado obligadas a asumir tal prestación.

Precisamente el origen de la controversia que suscita este tema, es atribuible a la sentencia C-425 de 2005 de la Corte Constitucional, mediante la cual, con ponencia del Dr. Jaime Araújo Rentería, se declaró inexequible el primer inciso del parágrafo primero del artículo primero de la Ley 776 del 2002, que establecía, "La existencia de patologías anteriores no es causa para aumentar el grado de incapacidad, ni las prestaciones que correspondan al trabajador".

Tal declaración de inexequibilidad abrió las puertas para que un gran volumen de casos, en los que en principio el asegurador de la seguridad social no tendría obligación de atender tales prestaciones, lo deba hacer, siendo obligado a pagar pensiones de invalidez, situación que desde el punto de vista puramente social aparece como expresión de una clara justicia equitativa, pero que desde el punto de vista jurídico y concretamente del aseguramiento de riesgos propios de la seguridad social, pudiesen carecer del sustento suficiente para lograr el cometido propuesto.

Como se dejó esbozado en las evaluaciones críticas de las sentencias analizadas, tanto el fallo de inexequibilidad de la Corte Constitucional, como los fallos de casación de la Sala Laboral de la Corte Suprema de Justicia proferidos después de aquél, han expuesto una serie de argumentos tendientes a sustentar jurídicamente las decisiones adoptadas, sin el suficiente soporte ni análisis del verdadero contenido obligacional asumido por las entidades administradoras del Sistema de Seguridad Social (riesgos laborales y pensiones), como tampoco de las consecuencias que sobre la sostenibilidad del mismo puedan tener dichos fallos.

Nos proponemos, antes de abordar el análisis concreto de la línea jurisprudencial, exponer de manera concreta los supuestos normativos que regulan el Sistema de Seguridad Social en relación con el riesgo específico de invalidez contenido en éste y la forma de aseguramiento del mismo a cargo tanto de las Administradoras de Fondos de Pensiones (en el caso de los riesgos comunes), como de las Administradoras de Riesgos Laborales. 


\subsection{EL ASEGURAMIENTO DEL RIESGO DE INVALIDEZ EN EL SISTEMA INTEGRAL DE SEGURIDAD SOCIAL EN COLOMBIA}

E1 Sistema Integral de Seguridad Social estatuido en Colombia a partir de la Ley 100 de 1993, está fundado sobre la base filosófico normativa de su preámbulo, así como de la descripción de su objeto y principios, destacándose que se trata del conjunto de instituciones, normas y procedimientos, de que disponen la persona y la comunidad para gozar de una calidad de vida, mediante el cumplimiento progresivo de los planes y programas que el Estado y la sociedad desarrollen para proporcionar la cobertura integral de las contingencias, especialmente las que menoscaban la salud y la capacidad económica, de los habitantes del territorio nacional, con el fin de lograr el bienestar individual y la integración de la comunidad.

El objeto del sistema se concreta en lograr la efectividad de los derechos aquí pregonados mediante la protección de las garantías que afecten la calidad de vida de los individuos, buscando esencialmente brindar cobertura de las prestaciones de carácter económico, de salud y de servicios complementarios, bajo principios de eficiencia, universalidad, solidaridad, integralidad, unidad y participación.

Se contempló que el Sistema debía estar dividido en tres "subsistemas" con propósitos de coberturas diversas, contemplándose el Sistema General de Pensiones, el Sistema de Salud y el Sistema General de Riesgos Laborales.

En lo que interesa a nuestro propósito académico, nos concentraremos en los subsistemas de Pensiones y Riesgos Laborales, pues fue a estos a los que se asignó la cobertura prestacional del riesgo de invalidez, estableciéndose para cada uno características y normativas diversas, en atención a la diferencia lógica que implica el cubrimiento de tal riesgo cuando se asegura por causas de origen común y cuando se asegura por causas de origen laboral.

\subsubsection{El aseguramiento del riesgo de invalidez en el sistema general de pensiones}

El Sistema General de Pensiones tiene por objeto, como lo indica el artículo 10 de la Ley 100 de 1993 “... garantizar a la población, el amparo contras las contingencias derivadas de la vejez, la invalidez y 
la muerte, mediante el reconocimiento de las pensiones y prestaciones que se determinan en la presente ley...".

Entre las características más sobresalientes de este Sistema, según se establece en su artículo 13, se cuentan:

- La afiliación es obligatoria para todos los trabajadores dependientes e independientes.

- Los afiliados tendrán derecho al reconocimiento y pago de las prestaciones de invalidez, vejez y sobrevivencia, conforme a lo dispuesto en la ley.

- La afiliación implica la obligación de efectuar los aportes que establece la ley y que serán a cargo del empleador y del trabajador en sus respectivos porcentajes.

El Sistema contempla además la coexistencia de dos regímenes administrados de manera diferente y por entidades distintas, pero vigilados ambos por el Estado y obligados a brindar las prestaciones contempladas. Ellos son: El Régimen de Prima Media con Prestación Definida (RPMPD) y el Régimen de Ahorro Individual con Solidaridad (RAICS).

Como es apenas obvio y por tratarse de un verdadero sistema de aseguramiento, se crearon unas reglas relativas a la forma de establecerse la cotización al sistema y la forma de administración de éstas. Para ello, el artículo 17 de la Ley 100 de 1993, modificado por el artículo 4 de la Ley 797 de 2003, estableció que durante la vigencia de la relación laboral y del contrato de prestación de servicios, deberán efectuarse cotizaciones obligatorias a los regímenes del sistema general de pensiones por parte de los afiliados, los empleadores y contratistas con base en el salario o ingresos por prestación de servicios que aquéllos devenguen y en los porcentajes establecidos en el artículo 20 de la Ley 100, modificado por el artículo 7 de la Ley 797 de 2003.

De manera concreta, en cuanto se refiere al aseguramiento del riesgo de invalidez, dispuso la norma en comento lo siguiente, aplicable para ambos regímenes:

ARTÍCULO. 38. Estado de invalidez. Para los efectos del presente capítulo se considera inválida la persona que por cualquier causa de origen no profesional, no provocada intencionalmente, hubiere perdido el $50 \%$ o más de su capacidad laboral. 
Se contemplaron además los siguientes requisitos para acceder a esta prestación:

Artículo 39. Requisitos para obtener la pensión de invalidez. Tendrá derecho a la pensión de invalidez el afiliado al sistema que conforme a lo dispuesto en el artículo anterior sea declarado inválido y acredite las siguientes condiciones:

1. Invalidez causada por enfermedad: Que haya cotizado cincuenta (50) semanas dentro de los últimos tres (3) años inmediatamente anteriores a la fecha de estructuración (y su fidelidad de cotización para con el sistema sea al menos del veinte por ciento (20\%) del tiempo transcurrido entre el momento en que cumplió veinte (20) años de edad y la fecha de la primera calificación del estado de invalidez.) EI texto entre paréntesis y subrayado fue declarado INEXEQUIBLE por la Corte Constitucional mediante Sentencia $\underline{\text { C-428 }}$ de 2009.

2. Invalidez causada por accidente: Que haya cotizado cincuenta (50) semanas dentro de los últimos tres (3) años inmediatamente anteriores al hecho causante de la misma, (y su fidelidad (de cotización para con el sistema sea al menos del veinte por ciento (20\%) del tiempo transcurrido entre el momento en que cumplió veinte (20) años de edad y la fecha de la primera calificación del estado de invalidez). El texto entre paréntesis y subrayado fue declarado INEXEQUIBLE por la Corte Constitucional mediante Sentencia $\underline{\mathrm{C}-428}$ de 2009.

Parágrafo $1^{\circ}$. Los menores de veinte (20) años de edad sólo deberán acreditar que han cotizado veintiséis (26) semanas en el último año inmediatamente anterior al hecho causante de su invalidez o su declaratoria.

Parágrafo $2^{\circ}$. Cuando el afiliado haya cotizado por lo menos el $75 \%$ de las semanas minimas requeridas para acceder a la pensión de vejez, solo se requerirá que haya cotizado 25 semanas en los últimos tres (3) años."

En cuanto al monto de la pensión de invalidez, el artículo 40 de la Ley 100 de 1993, dispuso:

"El monto mensual de la pensión de invalidez será equivalente a:

a) El $45 \%$ del ingreso base de liquidación, más el 1.5\% de dicho ingreso por cada cincuenta (50) semanas de cotización que el afiliado tuviese acreditadas con posterioridad a las primeras quinientas (500) semanas de cotización, cuando la disminución en su capacidad laboral sea igual o superior al 50\% e inferior al $66 \%, y$

b) El $54 \%$ del ingreso base de liquidación, más el $2 \%$ de dicho ingreso por cada cincuenta (50) semanas de cotización que el afiliado tuviese acreditadas con posterioridad a las primeras ochocientas (800) semanas de cotización, cuando la disminución en su capacidad laboral es igual o superior al $66 \%$.

La pensión por invalidez no podrá ser superior al 75\% del ingreso base de liquidación.

En ningún caso la pensión de invalidez podrá ser inferior al salario mínimo legal mensual. 
La pensión de invalidez se reconocerá a solicitud de parte interesada y comenzará a pagarse, en forma retroactiva, desde la fecha en que se produzca tal estado."

En cuanto a la financiación de la pensión de invalidez, debe señalarse que en el Régimen de Prima Media con Prestación Definida, ésta se efectuará con cargo al fondo común que se alimenta con las cotizaciones que administra hoy en día COLPENSIONES, mientras que en el Régimen de Ahorro Individual con Solidaridad, la financiación de la pensión de invalidez se sujeta a los saldos de la cuenta individual del afiliado más el capital que falte para garantizar el pago vitalicio de dicha prestación, que se encuentra a cargo de la Compañía de Seguros con la cual el Fondo de Pensiones respectivo haya contratado el seguro previsional para estos fines, como lo contempla el artículo 70 de la Ley 100 de 1993:

"ARTÍCULO. 70.- Financiación de la pensión de invalidez. Las pensiones de invalidez se financiarán con la cuenta individual de ahorro pensional del afiliado, el bono pensional si a éste hubiere lugar, y la suma adicional que sea necesaria para completar el capital que financie el monto de la pensión. La suma adicional estará a cargo de la aseguradora con la cual se haya contratado el seguro de invalidez $y$ de sobrevivientes.

El monto acumulado en las cuentas individuales de ahorro pensionad, en virtud de cotizaciones voluntarias, no hará parte del capital para financiar las pensiones de invalidez, salvo que asi lo disponga el afiliado, o cuando ello sea necesario para acceder a la pensión mínima de invalidez. El pensionado por invalidez podrá disponer del monto de las cotizaciones voluntarias no utilizado.

Cuando de conformidad con lo previsto en el artículo 44 de la presente ley se determine la cesación del estado de invalidez, la compañía de seguros deberá reintegrar a la cuenta individual de ahorro pensionad, el saldo no utilizado de la reserva para pensiones, en la parte que corresponda a capital más los rendimientos, de la cuenta de ahorro individual y al bono pensionad.

En los eventos de que trata el inciso anterior, los afiliados tendrán derecho a que el Estado les habilite como semanas cotizadas aquéllas durante las cuales gozaron de la respectiva pensión. Esta habilitación del número de semanas será aplicable sólo cuando el Estado deba pagar garantía de pensión mínima.

PARÁGRAFO.-El afiliado podrá contratar la pensión de invalidez con una aseguradora distinta de la que haya pagado la suma adicional a que se refiere el inciso primero de este artículo."

Se resalta pues, que en el caso del aseguramiento del riesgo de invalidez en el Régimen de Ahorro Individual con Solidaridad, aparece un tercer actor que puede llegar a verse afectado también por cuenta del problema que se plantea en el presente análisis jurisprudencial, pues si 
se obliga a la AFP a pagar de manera integral una pensión de invalidez en la que han concurrido porcentajes de pérdida de capacidad laboral tanto de origen común como de origen laboral, la aseguradora con la que tomó el seguro previsional para garantizar el cubrimiento de la suma restante que garantiza el pago vitalicio de la pensión, quedaría obligada (en principio) a asumir tal indemnización, de acuerdo con el contenido obligacional del contrato de seguro. Sin embargo, se resalta desde ya que puede surgir una controversia jurídica al respecto, pues la aseguradora podrá esgrimir la exclusión que le permite plantear la Resolución 530 de 1994 de la entonces Superintendencia Bancaria, en su artículo $2^{\circ}$ numeral $3^{\circ}$ "Exclusiones: la entidad aseguradora podrá excluir su responsabilidad solamente en los siguientes eventos: ... la invalidez o muerte originadas en accidente de trabajo o enfermedad profesional, no constituyen objeto de cobertura bajo este seguro".

\subsubsection{El aseguramiento del riesgo de invalidez en el sistema general de riesgos laborales}

Por su parte, el aseguramiento del riesgo de invalidez cuando se origina por un accidente de trabajo o una enfermedad laboral, encuentra su regulación normativa en un subsistema diferente, cual es del Sistema General de Riesgos Laborales.

Este sistema, está contemplado como el conjunto de normas, instituciones y procedimientos destinados a prevenir, proteger y atender los efectos que puedan ocasionar el accidente de trabajo y la enfermedad laboral respecto de los trabajadores (art. 1 Ley 1562 de 2012).

Entre los objetivos del sistema, se resalta especialmente el de "Reconocer y pagar a los afiliados las prestaciones económicas por incapacidad permanente parcial o invalidez, que se deriven de las contingencias de accidente de trabajo o enfermedad profesional y muerte de origen profesional..." (Decreto 1072 de 2015).

Este sistema, se encuentra normado principalmente en la Ley 100 de 1993, en el Decreto 1072 de 2015, en la Ley 776 de 2002 y en la Ley 1562 de 2012.

Sus características más relevantes son:

- Las entidades administradoras del Sistema general de riesgos laborales tendrán a su cargo la afiliación al sistema y la administración del mismo. 
- Todos los empleadores deben afiliarse al sistema.

- El empleador que no afilie a sus trabajadores al sistema, además de las sanciones legales, será responsable de las prestaciones que se otorgan en este decreto.

- Los trabajadores afiliados tendrán derecho al reconocimiento y pago de las prestaciones previstas en las normas que lo regulan.

- Las cotizaciones al sistema estarán a cargo de los empleadores.

Este Sistema tiene pues como esencia el aseguramiento de las contingencias que puedan sufrir los trabajadores en desarrollo de la actividad para la cual fueron contratados y se concretan en los riesgos de incapacidad temporal, incapacidad permanente, invalidez y muerte, causados por accidentes de trabajo ${ }^{1}$ y enfermedades laborales ${ }^{2}$.

Por tratarse también éste de un verdadero sistema de aseguramiento, la cobertura que brinda la Administradora de Riesgos Laborales a quien se le traslada el riesgo, tendrá como contraprestación una cotización que según el art. 16 del Decreto 1295 de 1994 ahora Decreto 1072 de 2015 corresponde al empleador y debe darse durante toda la vigencia de la relación laboral. Las tarifas se fijan con base en lo dispuesto en los artículos 17 y 19 de la Ley 776 de 2002 y 6 de la Ley 1562 de 2012. Por su parte, la distribución de dicha cotización, se efectuará como dispone el artículo 19 del Decreto 1295 de 1994, destacándose que un 94\% de dicho valor se destina para la cobertura de las contingencias aseguradas, incluyendo principalmente el pago de las prestaciones económicas y asistenciales que requieran los afiliados.

Para los propósitos del presente escrito, se resalta que entre las prestaciones económicas cuya cobertura se encuentra garantizada en este sistema, tenemos la pensión de invalidez de origen laboral, la cual se genera por la pérdida de capacidad laboral del trabajador, superior al $50 \%$ y que haya tenido como origen un accidente o una enfermedad laboral:

“ARTÍCULO 90. ESTADO DE INVALIDEZ. Para los efectos del Sistema General de Riesgos Profesionales, se considera inválida la persona que por causa de origen profesional, no provocada intencionalmente, hubiese perdido el cincuenta por ciento (50\%) o más de su capacidad laboral de acuerdo con el Manual Único de Calificación de Invalidez vigente a la fecha de la calificación. (...)"

1 Art. $3^{\circ}$ Ley 1562 de 2012.

2 Art. $4^{\circ}$ Ley 1562 de 2012. 
Ocurrida la contingencia, corresponderá a la Administradora de Riesgos Laborales pagar la respectiva pensión de invalidez, de acuerdo con los parámetros dispuestos en el artículo 10 de la Ley 776 de 2002:

ARTÍCULO 10. MONTO DE LA PENSIÓN DE INVALIDEZ. Todo afiliado al que se le defina una invalidez tendrá derecho, desde ese mismo día, a las siguientes prestaciones económicas, según sea el caso:

a) Cuando la invalidez es superior al cincuenta por ciento (50\%) e inferior al sesenta y seis por ciento (66\%), tendrá derecho a una pensión de invalidez equivalente al sesenta por ciento (60\%) del ingreso base de liquidación;

b) Cuando la invalidez sea superior al sesenta y seis por ciento (66\%), tendrá derecho a una pensión de invalidez equivalente al setenta y cinco por ciento (75\%) del ingreso base de liquidación;

c) Cuando el pensionado por invalidez requiere el auxilio de otra u otras personas para realizar las funciones elementales de su vida, el monto de la pensión de que trata el literal anterior se incrementa en un quince por ciento (15\%).

Parágrafo 10. Los pensionados por invalidez de origen profesional, deberán continuar cotizando al Sistema General de Seguridad en Salud, con sujeción a las disposiciones legales pertinentes.

Parágrafo 20. No hay lugar al cobro simultáneo de las prestaciones por incapacidad temporal y pensión de invalidez. Como tampoco lo habrá para pensiones otorgadas por los regímenes común y profesional originados en el mismo evento.

El trabajador o quien infrinja lo aquí previsto será investigado y sancionado de acuerdo con lo dispuesto en las leyes vigentes, sin perjuicio de las restituciones a que haya lugar por lo cobrado y obtenido indebidamente.

\subsubsection{Diferencias en el aseguramiento del riesgo de invalidez en el sistema general de pensiones $y$ en el sistema general de riesgos laborales}

Como se observa de lo anteriormente expuesto, el aseguramiento del riesgo de invalidez en el Sistema General de Pensiones y en el Sistema General de Riesgos Laborales, se presenta de manera diversa no sólo en el origen mismo de la contingencia, sino también en su forma de cobertura y en el pago de la prestación económica que se contempla.

En cuanto a la forma de cobertura, se puede ver que si bien en ambos sistemas se contemplan cotizaciones mensuales, el monto de éstas varía entre uno y otro, pues no debe olvidarse que se están amparando riesgos diversos, tanto en sus incidencias, como en sus frecuencias de ocurrencia e intensidades. Dichos riesgos, a su vez, se gestionan de manera diversa entre uno y otro sistema y además, obsérvese que mientras 
que el Sistema General de Pensiones, el cálculo de la cotización sólo depende de un parámetro objetivo dispuesto en la norma (monto del IBC), en el Sistema General de Riesgos Laborales, se tienen en cuenta una serie de aspectos técnicos como el tipo de actividad económica que se desarrolla el empleador, la incidencia de la siniestralidad, etc ${ }^{3}$.

En cuanto a los requisitos para que se genere la obligación de pagar la prestación económica, se observan también diferencias, pues mientras que en el Sistema General de Riesgos Laborales, sólo se exige que la invalidez se haya presentado como consecuencia de un accidente de trabajo o enfermedad laboral ocurridos dentro de la vigencia de la relación laboral cuyos riesgos fueron trasladados a una ARL, en el Sistema General de Pensiones se exige, además del estado de invalidez, que haya un cúmulo de semanas cotizadas con anterioridad a la fecha de estructuración de la ésta.

En este mismo aspecto, se puede observar también que mientras que en el Sistema de Riesgos Laborales la ARL es la única aseguradora del riesgo, en el Sistema de Pensiones, concretamente en el RAICS, la AFP no asume la totalidad del riesgo, pues traslada parte de éste a una

3 LEY 776 DE 2002. ARTÍCULO 19. DETERMINACIÓN DE LA COTIZACIÓN. Los literales del artículo 15 del Decreto-ley 1295 de 1994 quedarán así:

a) La actividad económica;

b) Un indicador de variación del índice de lesiones incapacitantes y de la siniestralidad de cada empresa;

c) El cumplimiento de las políticas y el plan de trabajo anual del programa de salud, ocupacional de empresa elaborado con la asesoría de la administradora de riesgos profesionales correspondiente y definido con base en los indicadores de estructura, proceso y resultado que establezca el Gobierno Nacional.

PARÁGRAFO. Todas las formulaciones y metodologías que se utilizan para la determinación de la variación de la cotización, son comunes para todas las Administradoras de Riesgos Profesionales y no pueden ser utilizadas para prácticas de competencia desleal, so pena de la imposición de multas correspondientes.

LEY 776 DE 2002. ARTÍCULO 20. VARIACIÓN DEL MONTO DE LA COTIZACIÓN. Los literales a) y b) del artículo $\underline{32}$ del Decreto-ley 1295 de 1994 quedarán así:

a) Un indicador de variación del índice de lesiones incapacitantes y de la siniestralidad de cada empresa;

b) El cumplimiento de las políticas y el plan de trabajo anual del programa de salud ocupacional de la empresa asesorado por la Administradora de Riesgos Profesionales correspondiente y definido con base en los indicadores de estructura, proceso y resultado que establezca el Gobierno Nacional.

PARÁGRAFO 1o. La variación del monto de las cotizaciones permanecerá vigente mientras se cumplan las condiciones que le dieron origen.

PARÁGRAFO 20. La variación del monto de cotizaciones solo podrá realizarse cuando haya transcurrido cuando menos un (1) año de la última afiliación del empleador.

PARÁGRAFO 3o. El Ministerio de Trabajo y Seguridad Social definirá con carácter general, las formulaciones y metodologías que se utilicen para la determinación de la variación de la cotización. Estas serán comunes para todas las Administradoras de Riesgos Profesionales y no pueden ser utilizadas para prácticas de competencia desleal, so pena de la imposición de las multas correspondientes. 
aseguradora por vía del seguro previsional para que quede a su cargo el pago de la suma faltante en la cuenta de ahorro individual para garantizar el pago vitalicio de la pensión de invalidez.

En cuanto al cálculo del monto de la pensión de invalidez, éste también es diferente en uno y otro sistema, como se observa de lo normado en el artículo 40 de la Ley 100 de 1993 (Pensiones) y en el artículo 10 de la Ley 776 de 2002 (Riesgos Laborales).

Todas las anteriores diferencias, permiten concluir que el aseguramiento del riesgo de invalidez en uno y otro sistema es diverso y por tanto, no puede pretenderse asignar responsabilidades prestacionales a cargo de uno sólo de ellos cuando se ha dado la realización de riesgos diversos de manera concurrente, pues se estará cargando a uno de estos sistemas la asunción de una obligación que no sólo no adquirió, sino que legalmente no puede asumir y además lo estará haciendo sin tener claridad sobre la forma de lograr su contraprestación económica, implicando un grave desequilibrio para las finanzas de la respectiva entidad aseguradora y para las del propio sistema.

\subsubsection{La calificación de la pérdida de capacidad laboral en el sistema integral de seguridad social}

Dada la importancia que reviste establecer el origen del porcentaje de pérdida de capacidad laboral que aqueja al trabajador, en orden a fijar a qué entidad del sistema corresponde asumir el pago de las prestaciones asistenciales y económicas contempladas, se hace imperativo contar con un sistema de calificación que garantice desde un punto de vista técnico pero también jurídico, una adecuada definición de tal problema, sin dejar de mencionar además, la necesidad de calificar el porcentaje de pérdida de capacidad laboral y la fecha de estructuración de ésta.

El sistema ha sufrido múltiples reformas en tal sentido, tendiéndose siempre hacia la unificación de procedimientos en aras de lograr un procedimiento de calificación que garanticen el debido proceso y el derecho de contradicción a todos los interesados.

En la actualidad el procedimiento de calificación encuentra su principal fuente normativa en el artículo 41 de la Ley 100 de 1993, modificado por el artículo 142 del Decreto Ley 019 de 2012: 
“Artículo 41.Calificación del Estado de Invalidez. El estado de invalidez será determinado de conformidad con lo dispuesto en los artículos siguientes y con base en el manual único para la calificación de invalidez vigente a la fecha de calificación. Este manual será expedido por el Gobierno Nacional y deberá contemplar los criterios técnicos de evaluación para calificar la imposibilidad que tenga el afectado para desempeñar su trabajo por pérdida de su capacidad laboral.

Corresponde al Instituto de Seguros Sociales, Administradora Colombiana de Pensiones -COLPENSIONES-, a las Administradoras de Riesgos Profesionales ARP-, a las Compañías de Seguros que asuman el riesgo de invalidez y muerte, y a las Entidades Promotoras de Salud EPS, determinar en una primera oportunidad la pérdida de capacidad laboral y calificar el grado de invalidez y el origen de estas contingencias. En caso de que el interesado no esté de acuerdo con la calificación deberá manifestar su inconformidad dentro de los diez (10) días siguientes y la entidad deberá remitirlo a las Juntas Regionales de Calificación de Invalidez del orden regional dentro de los cinco (5) días siguientes, cuya decisión será apelable ante la Junta Nacional de Calificación de Invalidez, la cual decidirá en un término de cinco (5) dias. Contra dichas decisiones proceden las acciones legales.

El acto que declara la invalidez que expida cualquiera de las anteriores entidades, deberá contener expresamente los fundamentos de hecho y de derecho que dieron origen a esta decisión, así como la forma y oportunidad en que el interesado puede solicitar la calificación por parte de la Junta Regional y la facultad de recurrir esta calificación ante la Junta Nacional.

Cuando la incapacidad declarada por una de las entidades antes mencionadas (ISS, Administradora Colombiana de Pensiones - Colpensiones -, ARP, aseguradora o entidad promotora de salud) sea inferior en no menos del diez por ciento (10\%) a los límites que califican el estado de invalidez, tendrá que acudirse en forma obligatoria a la Junta Regional de Calificación de Invalidez por cuenta de la respectiva entidad.

Para los casos de accidente o enfermedad común en los cuales exista concepto favorable de rehabilitación de la Entidad Promotora de Salud, la Administradora de Fondos de Pensiones postergará el trámite de calificación de Invalidez hasta por un término máximo de trescientos sesenta (360) días calendario adicionales a los primeros ciento ochenta (180) dias de incapacidad temporal reconocida por la Entidad Promotora de Salud, evento en el cual, con cargo al seguro previsional (sic) de invalidez y sobrevivencia o de la entidad de previsión social correspondiente que lo hubiere expedido, la Administradora de Fondos de Pensiones otorgará un subsidio equivalente a la incapacidad que venía disfrutando el trabajador.

Las Entidades Promotoras de Salud deberán emitir dicho concepto antes de cumplirse el día ciento veinte (120) de incapacidad temporal y enviarlo antes de cumplirse el día ciento cincuenta (150), a cada una de las Administradoras de Fondos de Pensiones donde se encuentre afiliado el trabajador a quien se le expida el concepto respectivo, según corresponda. Cuando la Entidad Promotora de Salud no expida el concepto favorable de rehabilitación, si a ello hubiere lugar, deberá pagar un subsidio equivalente a la respectiva incapacidad temporal 
después de los ciento ochenta (180) días iníciales con cargo a sus propios recursos, hasta cuando se emita el correspondiente concepto.

Inciso adicionado por el artículo 18 de la Ley 1562 de 2012. Sin perjuicio de lo establecido en este artículo, respecto de la calificación en primera oportunidad, corresponde a las Juntas Regionales calificar en primera instancia la pérdida de capacidad laboral, el estado de invalidez y determinar su origen.

A la Junta de Calificación Nacional compete la resolución de las controversias que en segunda instancia sean sometidas para su decisión por las Juntas Regionales.

La calificación se realizará con base en el manual único para la calificación de invalidez, expedido por el Gobierno Nacional, vigente a la fecha de calificación, que deberá contener los criterios técnicos-científicos de evaluación y calificación de pérdida de capacidad laboral porcentual por sistemas ante una deficiencia, discapacidad y minusvalía que havan generado secuelas como consecuencia de una enfermedad 0 accidente.

Obsérvese que mediante la adición a este artículo del inciso según lo dispuesto en el artículo 18 de la Ley 1562 de 2012, el legislador quiso promover un principio de solución a la controversia suscitada por la Corte Constitucional y que es objeto de nuestro análisis, pues ordena a las Juntas de Calificación de Invalidez tener en cuenta a la hora de emitir su calificación, el análisis de la misma discriminada por sistemas, es decir, distinguiendo qué porcentaje de disminución de capacidad laboral es atribuible a un riesgo común (caso en el cual lo asumirían los sistemas de salud y/o pensiones) y qué porcentaje será atribuible a un riesgo laboral (caso en el cual lo asumiría el sistema de riesgos laborales) ${ }^{4}$.

Por su parte, la calificación deberá efectuarse con base en el Manual Único de Calificación de Invalidez, contenido en el Decreto 917 de 1999 para las solicitudes de calificación presentadas antes del 12 de febrero de 2014, y con base en el Decreto 1507 de 2014 las posteriores a esa fecha, en el cual se regulan, entre otras, desde una perspectiva técnica, aspectos tales como:

Definición de Invalidez:

Decreto 917 de 1999:

"ARTÍCULO 20. DEFINICIONES DE INVALIDEZ, INCAPACIDAD PERMANENTE PARCIAL, CAPACIDAD LABORAL Y TRABAJO HABITUAL. Para efecto de la aplicación y cumplimiento del presente decreto, adóptanse las siguientes definiciones:

4 Cortés González, Juan Carlos. Régimen de los riesgos laborales en Colombia. Editorial Legis S.A. Bogotá, 2012, primera edición, págs. 267 y ss 
a) Invalidez: Se considera con invalidez la persona que por cualquier causa, de cualquier origen, no provocada intencionalmente, hubiese perdido el $50 \%$ o más de su capacidad laboral.

..."

Decreto 1507 de 2014:

"Artículo $3^{\circ}$. Definiciones. Para efectos de la aplicación del presente decreto, se adoptan las siguientes definiciones:

(...)

Capacidad laboral: Conjunto de habilidades, destrezas, aptitudes y/o potencialidades de orden físico, mental y social, que permiten desempeñarse en un trabajo.

(...)

Incapacidad permanente parcial: Es la disminución definitiva, igual o superior al cinco por ciento (5\%) e inferior al cincuenta por ciento (50\%) de la capacidad laboral u ocupacional de una persona, como consecuencia de un accidente o de una enfermedad de cualquier origen.

Invalidez: Es la pérdida de la capacidad laboral u ocupacional igual o superior al cincuenta por ciento (50\%).

(...)

Trabajo habitual: Aquel oficio o labor que desempeña la persona con su capacidad laboral, entrenamiento y/o formación técnica o profesional, recibiendo una remuneración.

Definición de fecha de estructuración o declaratoria de la pérdida de la capacidad laboral:

Decreto 917 de 1999:

"ARTÍCULO 30. FECHA DE ESTRUCTURACIÓN O DECLARATORIA DE LA PÉRDIDA DE LA CAPACIDAD LABORAL. Es la fecha en que se genera en el individuo una pérdida en su capacidad laboral en forma permanente $y$ definitiva. Para cualquier contingencia, esta fecha debe documentarse con la historia clínica, los exámenes clínicos y de ayuda diagnóstica, y puede ser anterior o corresponder a la fecha de calificación. En todo caso, mientras dicha persona reciba subsidio por incapacidad temporal, no habrá lugar a percibir las prestaciones derivadas de la invalidez."

Decreto 1507 de 2014:

“Artículo $3^{\circ}$. Definiciones. Para efectos de la aplicación del presente decreto, se adoptan las siguientes definiciones:

Fecha de declaratoria de la pérdida de la capacidad laboral: Fecha en la cual se emite una calificación sobre el porcentaje de la pérdida de capacidad laboral u ocupacional.

Fecha de estructuración: Se entiende como la fecha en que una persona pierde un grado o porcentaje de su capacidad laboral u ocupacional, de cualquier origen, como consecuencia de una enfermedad o accidente, y que se determina con base en la evolución de las secuelas que han dejado estos. Para el estado de 
invalidez, esta fecha debe ser determinada en el momento en el que la persona evaluada alcanza el cincuenta por ciento (50\%) de pérdida de la capacidad laboral u ocupacional.

Esta fecha debe soportarse en la historia clínica, los exámenes clínicos y de ayuda diagnóstica y puede ser anterior o corresponder a la fecha de la declaratoria de la pérdida de la capacidad laboral. Para aquellos casos en los cuales no exista historia clínica, se debe apoyar en la historia natural de la enfermedad. En todo caso, esta fecha debe estar argumentada por el calificador y consignada en la calificación. Además, no puede estar sujeta a que el solicitante haya estado laborando y cotizando al Sistema de Seguridad Social Integral”.

\section{Criterios para la calificación de la invalidez:}

Decreto 917 de 1999:

"ARTÍCULO 70. CRITERIOS PARA LA CALIFICACION INTEGRAL DE INVALIDEZ. Para efecto de la calificación integral de la invalidez se tendrán en cuenta los componentes funcionales biológico, psíquico y social del ser humano, entendidos en términos de las consecuencias de la enfermedad, el accidente o la edad, $y$ definidos de la siguiente manera:

a) DEFICIENCIA: Se entiende por deficiencia, toda pérdida o anormalidad de una estructura o función psicológica, fisiológica o anatómica, que pueden ser temporales o permanentes, entre las que se incluyen la existencia o aparición de una anomalía, defecto o pérdida producida en un miembro, órgano, tejido u otra estructura del cuerpo humano, así como también los sistemas propios de la función mental. Representa la exteriorización de un estado patológico y en principio refleja perturbaciones a nivel del órgano.

b) DISCAPACIDAD: Se entiende por Discapacidad toda restricción o ausencia de la capacidad de realizar una actividad en la forma o dentro del margen que se considera normal para un ser humano, producida por una deficiencia, y se caracteriza por excesos o insuficiencias en el desempeño y comportamiento en una actividad normal o rutinaria, los cuales pueden ser temporales o permanentes, reversibles o irreversibles, y progresivos o regresivos. Representa la objetivación de la deficiencia y por tanto, refleja alteraciones al nivel de la persona.

c) MINUSVALÍA: Se entiende por Minusvalía toda situación desventajosa para un individuo determinado, consecuencia de una deficiencia o una discapacidad que lo limita o impide para el desempeño de un rol, que es normal en su caso en función de la edad, sexo, factores sociales, culturales y ocupacionales. Se caracteriza por la diferencia entre el rendimiento y las expectativas del individuo mismo o del grupo al que pertenece. Representa la socialización de la deficiencia y su discapacidad por cuanto refleja las consecuencias culturales, sociales, económicas, ambientales y ocupacionales, que para el individuo se derivan de la presencia de las mismas y alteran su entorno."

Decreto 1507 de 2014:

"Articulo $3^{\circ}$. Definiciones. Para efectos de la aplicación del presente decreto, se adoptan las siguientes definiciones: 
Deficiencia: Alteración en las funciones fisiológicas o en las estructuras corporales de una persona. Puede consistir en una pérdida, defecto, anomalía o cualquier otra desviación significativa respecto de la norma estadísticamente establecida.

Discapacidad: Término genérico que incluye limitaciones en la realización de una actividad, esta se valorará en el Título Segundo "Valoración del Rol Laboral, Rol Ocupacional y otras áreas Ocupacionales”.

(...)

Minusvalía: Se entiende por minusvalía toda situación desventajosa para un individuo determinado, consecuencia de una deficiencia o una discapacidad que le impide o limita para el desempeño de un rol, que es normal en su caso, en función de la edad, sexo, factores sociales, culturales y ocupacionales. Se caracteriza por la diferencia entre el rendimiento y las expectativas del individuo mismo o del grupo al que pertenece. Representa la socialización de la deficiencia y su discapacidad, por cuanto refleja las consecuencias culturales, sociales, económicas, ambientales y ocupacionales, que para el individuo se derivan de la presencia de las mismas y alteran su entorno. Esta se valorará en el Título Segundo "Valoración del rol laboral, rol ocupacional y otras áreas ocupacionales".

Respecto de la distribución porcentual para la calificación:

Decreto 917 de 1999:

"ARTÍCULO 80. DISTRIBUCIÓN PORCENTUAL DE LOS CRITERIOS PARA LA CALIFICACIÓN TOTAL DE LA INVALIDEZ. Para realizar la calificación integral de la invalidez, se otorga un puntaje a cada uno de los criterios descritos en el artículo anterior, cuya sumatoria equivale al $100 \%$ del total de la pérdida de la capacidad laboral, dentro de los siguientes rangos máximos de puntaje:

\begin{tabular}{|l|c|}
\hline CRITERIO & PORCENTAJE (\%) \\
\hline Deficiencia & 50 \\
\hline Discapacidad & 20 \\
\hline Minusvalía & 30 \\
\hline Total & $\mathbf{1 0 0}$ \\
\hline
\end{tabular}

PARÁGRAFO 1. Cuando no exista deficiencia o su valor sea cero (0) no podrá calificarse la discapacidad ni la minusvalía. Por tanto, la pérdida de la capacidad laboral resultante se reportará con un valor de cero (0).

PARÁGRAFO 2. En concordancia con el parágrafo 1 del artículo 34 del Decreto-ley 1295 de 1994, para la calificación en el caso de accidente de trabajo y enfermedad profesional, la existencia de patologías anteriores no es causa para aumentar el grado de incapacidad, ni las prestaciones que correspondan al trabajador. De igual manera, cuando existan deficiencias de origen congénito 0 adquiridas antes de cumplir con las edades mínimas legales para trabajar $\mathrm{y}$ el individuo hava sido habilitado ocupacional $\mathrm{y}$ socialmente, estas deficiencias no se tendrán en cuenta para la calificación 
de la pérdida de la capacidad laboral de origen profesional, a no ser que se havan agravado o havan aparecido otras. (...)”

(Subrayas y negrilla fuera del texto original).

Anexo técnico del Decreto 1507 de 2014:

Principio de Integralidad. El Manual acoge el principio general de "integralidad" como soporte de la metodología que se expondrá en adelante para calificar las deficiencias en la capacidad laboral u ocupacional. La integralidad es referida al Modelo de la Ocupación Humana que describe al ser humano desde tres componentes interrelacionados: volición, habituación y capacidad de ejecución; estos tres aspectos tienen en cuenta los componentes biológico, psíquico y social de las personas y permiten establecer y evaluar la manera como se relacionan con su ambiente. La calificación integral de la invalidez, es decir del 50\% o más de pérdida de la capacidad laboral, procede conforme a lo dispuesto en la Sentencia C-425 de 2005 de la Corte Constitucional y su precedente jurisprudencial; que dispone que las entidades competentes deberán hacer una valoración integral, que comprenda tanto los factores de origen común como los de índole laboral.

3. Principios de ponderación. Para efectos de calificación, el Manual Único para la Calificación de la Pérdida de Capacidad Laboral y Ocupacional, se distribuye porcentualmente de la siguiente manera: El rango de calificación oscila entre un mínimo de cero por ciento (0\%) y un máximo de cien por ciento (100\%), correspondiendo, cincuenta por ciento (50\%) al Título Primero (Valoración de las deficiencias) y cincuenta por ciento (50\%) al Título Segundo (Valoración del rol laboral, rol ocupacional y otras áreas ocupacionales) del Anexo Técnico.

(...)

Respecto de la norma recién citada y resaltada del Decreto 917 de 1999, debe tenerse en cuenta que de acuerdo con el contenido de la sentencia C-425 de 2005, esta disposición tampoco sería aplicable en el ordenamiento, pues está redactada en el mismo sentido que el parágrafo primero del artículo primero de la Ley 776 de 2002, aplicándosele los mismos efectos de inconstitucionalidad, razón por la cual, y tal como se expresa en el anexo técnico del Decreto 1507 de 2014, es la norma que reemplaza la del anterior Decreto, incorporando como lo indica de manera literal el contenido de la sentencia C-425 de 2005.

Pero no sólo corresponde a las Juntas de Calificación de Invalidez atenerse a los mandatos de este Manual, sino que también deben desarrollar su actividad bajo los parámetros de las normas que reglamentan su funcionamiento, encontrándose vigente en la actualidad el Decreto 1072 de 2015 que compiló el Decreto 1352 de 2013, de donde se resalta, para los efectos de nuestro análisis, el siguiente artículo: 
“Artículo 2.2.5.1.50. Procedimiento aplicado para la calificación integral de la invalidez.

Las solicitudes que lleguen a las Juntas Regionales de Calificación de Invalidez y la Nacional por parte de las Administradoras de Riesgos Laborales o las Administradoras del Fondo de Pensiones, las Entidades Promotoras de Salud o las Compañias de Seguros que asuman el riesgo de invalidez y muerte, las Administradoras del Sistema General de Pensiones, deben contener la calificación integral para la invalidez de conformidad la sentencia C-425 de 2005 de la Honorable Corte Constitucional y su precedente jurisprudencial, esto mismo aplicará para el correspondiente dictamen por parte de las Juntas de Calificación de Invalidez Regional o Nacional. (Subraya y negrilla fuera del texto original).

Obsérvese pues, como en esta norma, también se tienen en cuenta los efectos de la sentencia C-425 de 2005, ordenándose en consecuencia que siempre que se haga una calificación, bien a cargo de una de las entidades del sistema que tienen a su cargo los riesgos de invalidez y muerte o bien las Juntas Regionales y Nacional de calificación de invalidez, deberá efectuarse siempre la calificación de manera integral.

\section{LINEA JURISPRUDENCIAL SEGUIDA POR LA CORTE CONSTITUCIONAL Y LA SALA LABORAL DE LA CORTE SUPREMA DE JUSTICIA A PARTIR DE LA SENTENCIA C-425 DE 2005.}

Hemos planteado cómo es la forma de aseguramiento del riesgo de invalidez en la legislación colombiana vigente, tanto aquél de origen común como aquél de origen laboral, por lo cual, cabe preguntarse si los efectos de la decisión efectuada por la Corte Constitucional en sentencia C-425 de 2005 al declarar inexequible el parágrafo $1^{\circ}$ del artículo $1^{\circ}$ de la Ley 776 de 2002, son realmente justos desde el punto de vista del sistema de aseguramiento del riesgo concreto de invalidez que tienen a su cargo tanto las entidades del Sistema General de Pensiones, como las del Sistema General de Riesgos Laborales.

La norma declarada inexequible parcialmente es la siguiente:

“LEY 776 DE 2002. ARTÍCULO 10. DERECHO A LAS PRESTACIONES. Todo afiliado al Sistema General de Riesgos Profesionales que, en los términos de la presente ley o del Decreto-ley 1295 de 1994, sufra un accidente de trabajo o una enfermedad profesional, o como consecuencia de ellos se incapacite, se invalide o muera, tendrá derecho a que este Sistema General le preste los servicios 
asistenciales y le reconozca las prestaciones económicas a los que se refieren el Decreto-ley 1295 de 1994 y la presente ley.

(PARÁGRAFO 1o. INEXEQUIBLE. La existencia de patologías anteriores no es causa para aumentar el grado de incapacidad, ni las prestaciones que correspondan al trabajador.) Corte Constitucional Sentencia C-425 de 2005

PARÁGRAFO 20. Las prestaciones asistenciales y económicas derivadas de un accidente de trabajo o de una enfermedad profesional, serán reconocidas y pagadas por la administradora en la cual se encuentre afiliado el trabajador en el momento de ocurrir el accidente o, en el caso de la enfermedad profesional, al momento de requerir la prestación.

Cuando se presente una enfermedad profesional, la administradora de riesgos profesionales que asume las prestaciones, podrá repetir proporcionalmente por el valor pagado con sujeción y, en la misma proporción al tiempo de exposición al riesgo que haya tenido el afiliado en las diferentes administradoras, entidades o a su empleador de haber tenido periodos sin cobertura.

Para enfermedad profesional en el caso de que el trabajador se encuentre desvinculado del Sistema de Riesgos Profesionales, y la enfermedad sea calificada como profesional, deberá asumir las prestaciones la última administradora de riesgos a la cual estuvo vinculado, siempre y cuando el origen de la enfermedad pueda imputarse al periodo en el que estuvo cubierto por ese Sistema.

La Administradora de Riesgos Profesionales en la cual se hubiere presentado un accidente de trabajo, deberá responder integramente por las prestaciones derivados de este evento, tanto en el momento inicial como frente a sus secuelas, independientemente de que el trabajador se encuentre o no afiliado a esa administradora.

Las acciones de recobro que adelanten las administradoras son independientes a su obligación de reconocimiento del pago de las prestaciones económicas dentro de los dos (2) meses siguientes contados desde la fecha en la cual se alleguen o acrediten los requisitos exigidos para su reconocimiento. Vencido este término, la administradora de riesgos profesionales deberá reconocer y pagar, en adición a la prestación económica, un interés moratorio igual al que rige para el impuesto de renta y complementarios en proporción a la duración de la mora. Lo anterior, sin perjuicio de las sanciones a que haya lugar.

PARÁGRAFO 30. El Gobierno Nacional establecerá con carácter general un régimen para la constitución de reservas, que será igual para todas las Administradoras del Sistema, que permitan el cumplimiento cabal de las prestaciones económicas propias del Sistema.

La Superintendencia Bancaria establecerá en el plazo de un (1) año de la entrada en vigencia de la presente ley un esquema para que el ISS adopte el régimen de reservas técnicas establecido para las compañias de seguros que tengan autorizado el ramo de riesgos profesionales, dicho Instituto continuará manejando separadamente dentro de las reservas de ATEP aquellas que amparan el capital de cobertura para las pensiones ya reconocidas y el saldo se destinará a constituir separadamente las reservas para cubrir las prestaciones económicas de las enfermedades profesionales de que trata este artículo. Una vez se agote la reserva de enfermedad profesional, el presupuesto nacional deberá girar los recursos para amparar el pasivo si lo hubiere contemplado en el presente 
parágrafo, y el Instituto procederá a pagar a las administradoras de riesgos profesionales que repitan contra él."

El aparte declarado inexequible tenía pleno sustento jurídico, pues la Ley 776 de 2002, fue expedida con el propósito de establecer por vía de Ley de la República las prestaciones económicas a que tienen derecho los afiliados al Sistema General de Riesgos Laborales, haciéndose inexorable establecer los límites del aseguramiento a cargo de las Administradoras de Riesgos Laborales respecto de las demás entidades aseguradoras del Sistema Integral de Seguridad Social.

Resultaba apenas obvio que la norma contemplara que la existencia de patologías anteriores al estado actual del afiliado que pretendía calificarse, no podían ser tenidas en cuenta para aumentar el grado de calificación de pérdida de capacidad laboral, pues se le estaría cargando a la Administradora de Riesgos Laborales una obligación económica que no tenía contemplada en el estado del riesgo que asumió, sin dejar de mencionar que lo estaría haciendo de manera gratuita, pues respecto de dicho riesgo originado de manera común no percibe contraprestación alguna a título de cotización, como sí lo podría estar haciendo una AFP que no verá afectado su patrimonio, pues finalmente no le corresponderá pagar tal prestación.

No obstante la claridad conceptual y teleológica que podía tener la norma declarada inexequible, la Corte Constitucional, sustentada en los argumentos expuestos en nuestra reseña, que valga la oportunidad decir, corresponden a justificaciones de carácter mayormente sociales que jurídicas, decidió eliminarla del ordenamiento, abriendo la puerta para que se obligara a entidades del sistema de seguridad social a asumir riesgos para los cuales no asumió responsabilidad alguna ni de manera contractual ni mucho menos legal y lo que es peor, sin contraprestación económica alguna, poniendo en serio peligro la sostenibilidad del sistema.

Esta misma posición asumida por la Corte Constitucional ha venido siendo reiterada por dicha Corporación, como se observa en la reseñada sentencia T-518 de 2011, en la que de igual manera, con base en las consideraciones tenidas en cuenta en la sentencia C-425 de 2005, se decidió revocar los fallos de instancia, para ordenar a la ARL vinculada y la Junta de Calificación de Invalidez, efectuar nuevamente la calificación de invalidez, bajo los criterios dispuestos por la Corte, que se concretan en que deberá efectuarse una "calificación integral" detallándose los 
factores de discapacidad, discriminándose detalladamente los porcentajes de pérdida de capacidad laboral y las causas que los generan.

Podría pensarse que los razonamientos expuestos por la Corte Constitucional corresponden con su tradicional posición de protección especial de sujetos en estado de vulnerabilidad, que origina a partir de su interpretación, a veces extrema, del artículo 13 Superior, sin embargo, se observa con preocupación que también la Sala de Casación Laboral de la Corte Suprema de Justicia ha adoptado una posición en la misma dirección que la de la Corte Constitucional y, como se indicó en las respectivas reseñas, ha optado por imponer a administradoras de riesgos laborales la asunción completa de pensiones de invalidez que están integradas por porcentajes de calificación en parte de origen común y en parte de origen laboral, generando un consecuente y preocupante desequilibrio dentro del sistema, al asignarle un riesgo que no ha asumido, no ha gestionado, ni mucho menos calculado.

Concretamente, en las sentencias del 24 de julio de 2012, con ponencia del Dr. Rigoberto Echeverri Bueno, expediente 37.892 y del 26 Junio 2012, con ponencia del Dr. LUIS GABRIEL MIRANDA BUELVAS, expediente 38.614, la Sala Laboral funda su decisión de no casar los fallos acusados por las ARL recurrentes, en la noción de la "integralidad" que campea en todo el Sistema de Seguridad Social, señalando que tiene un valor superior en tanto traza la filosofía y los principios que rigen éste, pero consideramos que no deja de ser ésta una posición más axiológica que jurídica, pues a continuación expone la Corte que si bien no existe una norma explícita y expresa que establezca la posibilidad de asignar responsabilidades a una sola entidad por una pensión de invalidez derivada de la sumatoria de porcentajes de pérdida de capacidad laboral con distintos orígenes, ello no puede significar que los jueces se abstengan de ordenar el pago de las pensiones correspondientes.

Se nota en esta línea argumentativa una clara ausencia de base normativa que permita sustentar la posición de la Corte, tal como ella misma lo asevera, pues ante la ausencia de norma que expresamente obligue a una determinada aseguradora del sistema a asumir riesgos ajenos a su rol, se generará un desequilibrio contractual y un desajuste económico del sistema, en la medida que se tendrá que asumir el pago (vitalicio en la mayoría de los casos) de una pensión de invalidez generada en parte por un riesgo respecto del cual no recibió el pago de cotización alguna, con el agravante, que ni la ley ni la jurisprudencia han contemplado de 
manera concreta las formas de recobro o reembolso que puedan hacerse entre entidades y actores del sistema por tal concepto.

Señala la Corte que el argumento de la ARL recurrente en casación en cuanto a que la mesada pensional debe ser reconocida por cada subsistema de manera proporcional al riesgo, no tiene sustento jurídico, por cuanto violaría el principio de "indivisibilidad de la mesada pensional", respecto del cual, acepta la Corte, no existe fundamento normativo, pero que está implícito en el sistema.

Señala la Corte que este principio de indivisibilidad se origina en varios supuestos normativos que prohíben cualquier fórmula para dividir o prorratear la pensión entre varios obligados, tales como el caso en que varias entidades deben concurrir al pago de una pensión de jubilación y la ley radica en una de ellas la obligación de pagarla total y directamente, con la posibilidad de repetir o exigir las cuotas partes a las restantes por las porciones respectivas, sin que haya lugar a fraccionamiento alguno en el pago que se hace al trabajador, o la solución implementada por el legislador para el caso de enfermedades profesionales que se estructuran y desarrollan durante la afiliación a varias administradoras, en el sentido de asignar la responsabilidad del reconocimiento a la última, preservando la posibilidad de repetición proporcional contra las otras o el empleador, según lo contempló el parágrafo 2 inciso 2 del artículo 1 de la Ley 776 de 2002.

Consideramos frente a este punto que le asiste razón a la Corte cuando señala la improcedencia práctica y la ausencia de garantía que implicaría para un pensionado tener que acudir ante dos entidades diferentes a recibir fraccionadamente su mesada pensional, pero ello no es óbice para que no se tengan en cuenta elementales razones de respeto por el derecho de defensa que les asiste a las administradoras del sistema al momento de verse convocadas a un proceso judicial, en el que se pretende declararlas responsables por el pago de una pensión de invalidez compuesta por porcentajes de pérdida de capacidad laboral de diversos orígenes, uno de los cuales no ha asumido dicho asegurador, sin que la Corte plantee tampoco un criterio claro que permita establecer cuándo le corresponderá a dicho asegurador asumir el pago total de la pensión y cuándo le corresponderá al asegurador del otro riesgo.

Como lo indicamos en la evaluación crítica de estas sentencias, la Sala Laboral ni siquiera tiene en cuenta los parámetros contemplados en la sentencia T-518 de 2011, especialmente en lo que tiene que ver 
con el criterio cronológico para la determinación del subsistema que debe asumir la pensión de invalidez cuando la pérdida de capacidad laboral que la origina derivada de patologías de origen laboral y común.

De lo anterior se observa la ausencia de claridad en los fundamentos de las sentencias analizadas, a la hora de establecer criterios para la asignación de responsabilidades a los aseguradores del sistema, pues por ejemplo en el caso de la sentencia 38.614, la enfermedad de origen común que generó cronológicamente hablando la invalidez del demandante fue posterior a la enfermedad laboral de la que ya se había pagado incluso la indemnización permanente parcial, por lo que si se siguiera el criterio de la Corte Constitucional trazado en la sentencia T-518 de 2011, el resultado hubiera sido que la pensión debiera ser asumida por la AFP y no por la ARL, y como el primero (la AFP) no fue parte en el proceso, entonces se habrían despachado de manera desfavorable las pretensiones de la demanda.

Lo anterior suscita un conflicto de enorme importancia, pues así como está planteado el problema por la Corte Suprema de Justicia, la asignación de la responsabilidad en el pago de la pensión de invalidez a uno de los aseguradores, estará supeditado casi que al azar y a la forma como fortuitamente se den las circunstancias del caso concreto, aspectos totalmente contrarios a los principios que rigen el contrato de seguro en Colombia, pues riñen con la definición del riesgo contemplada en el artículo 1054 C. de Co., especialmente en cuanto se refiere a la incertidumbre de éste, mostrándose también contrario al principio de asunción de riesgos que contempla el artículo 1056, por cuanto se estará obligando al asegurador a asumir riesgos que no ha escogido amparar, como sería el caso de una Administradora de Riesgos Laborales que termina siendo obligada a pagar una pensión de invalidez compuesta en parte por una pérdida de capacidad laboral de origen común, riesgo que además pudo haberse concretado antes de asumir el riesgo laboral de ese trabajador en particular.

Piénsese por ejemplo en que en ambas sentencias analizadas de la Corte Suprema, se asignan responsabilidades a las Administradoras de Riesgos Laborales obligándolas a pagar pensiones de invalidez que en parte se han originado en riesgos comunes, con las críticas ya efectuadas, pero además, se nota en los dos casos concretos aludidos en los fallos, que las condenas impuestas a las ARL se terminan dando porque fueron las únicas vinculadas al proceso judicial, dado que los respecti- 
vos Fondos de Pensiones ni fueron demandados, ni fueron vinculados al proceso en calidad alguna, denotándose que por tratarse de la decisión de recursos extraordinarios de casación, ya no había oportunidad procesal para vincular a las respectivas AFP y asignarles las responsabilidades del caso, sin que le quedara a la Corte alternativa distinta que mantener los fallos de instancia con las respectivas condenas contra las ARL, obligándolas a asumir el pago integral de las pensiones de invalidez en debate.

En concreto, en la sentencia de 26 de mayo de 2012, radicación 38614 , la Corte afirma que dado que la AFP no fue parte del proceso, le correspondía pagar la totalidad de la pensión a la ARL, pero que ello no significa de manera alguna la existencia de una obligación solidaria, sin embargo, consideramos que en la práctica, el fallo sí termina asignando a la ARL los efectos de las obligaciones solidarias, pues la Corte analiza de manera indistinta la aludida "integralidad" del sistema, concluyendo que si la suma de los porcentajes de pérdida de capacidad laboral de origen común y origen laboral son iguales o superiores al 50\%, se generará una pensión de invalidez a favor del afiliado que al final determinó que debía asumir, en su totalidad, la entidad que estaba vinculada al proceso, es decir, la ARL, lo cual no es otra cosa que los puros y claros efectos de una obligación solidaria, lo que resulta contrario a la normativa vigente y a la estructura misma del sistema, ya que las obligaciones derivadas de los contratos por regla general son divisibles, especialmente en lo que tiene que ver con las prestaciones derivadas del sistema, las cuales están establecidas de manera clara en el contenido obligacional de cada uno de los subsistemas en concordancia con su respectivo cubrimiento, imponiéndoles el deber de la administración ajustada a la Ley de los recursos, lo cual de contera impide que existe solidaridad entre ellos, y así evitar que, por ejemplo, prestaciones derivadas de una accidente de trabajo sean asumidos por el sistema de pensiones y viceversa.

En la práctica es indudable la posibilidad de que en una misma persona confluyan pérdidas de capacidad laboral de diversos orígenes, que sumados la hacen materialmente inválida, haciendo posible que si esta persona está afiliada al Sistema General de Seguridad Social tenga derecho a acceder a una pensión de invalidez por presentar patologías o contingencias de diferentes orígenes, pero es también innegable que deberá establecerse de manera clara y precisa a qué subsistema le corresponde asumir la parte de esa invalidez que es originada por el riesgo 
amparado, sin que quede sometido casi al azar (criterio cronológico), desequilibrándolo y generando inequidad en la asunción de los riesgos.

Por ello consideramos que, mientras no haya normatividad expresa que resuelva el problema, el Juez Laboral, al definir estos litigios, deberá vincular procesalmente a los aseguradores potencialmente responsables y establecer de manera clara cómo operarán los reembolsos entre los aseguradores involucrados y en qué términos deben efectuarse. No se olvide que los jueces deben preocuparse tanto por la situación del trabajador afiliado como por la sostenibilidad del sistema y el impacto de sus decisiones.

Como se ha expuesto, creemos que las decisiones adoptadas por la Corte Constitucional y la Sala Laboral de la Corte Suprema de Justicia sobre la materia, han estado fundadas en la necesidad de solucionar problemas jurídicos concretos que se han dado en cada uno de los casos particulares sometidos a su jurisdicción, otorgando con criterios humanísticos y sociales el derecho pensional de invalidez a los respectivos actores, actitud que podría ser plausible si estuviera acompañada por un análisis más profundo del problema planteado, que dé solución a la necesidad concreta que implica para el individuo que materialmente se encuentra inválido, pero que a la vez importe el respeto por el contenido obligacional que contractual y legalmente asume cada asegurador en su respectivo sistema, al aceptar el traslado de unos determinados y concretos riesgos que, como vimos concretamente en el caso de la invalidez, tienen contenidos y formas de cobertura diversas tanto en el sistema de pensiones como en el de riesgos laborales.

Por ello, creemos que existe la posibilidad de resolver tal dicotomía sobre la base de la fijación de criterios claros que garanticen a los afiliados al sistema la posibilidad de ser beneficiarios de una pensión de invalidez cuando concurran en ella pérdidas de capacidad laboral de diversos orígenes, permitiéndose que se respete el contenido obligacional asumido por cada asegurador así como su derecho fundamental al debido proceso.

De hecho, como se señaló anteriormente, la reciente normatividad expedida contiene postulados que parecen buscar una solución normativa del problema, sin asirlo aun totalmente. Tal es el caso del artículo 18 de la Ley 1562 de 2012, que adicionó un inciso al artículo 41 de la Ley 100, modificado por el artículo 142 del Decreto 19 de 2012, señalando los criterios que debe tener en cuenta la entidad calificadora al 
momento de rendir su dictamen: "La calificación se realizará con base en el manual único para la calificación de invalidez, expedido por el Gobierno Nacional, vigente a la fecha de calificación, que deberá contener los criterios técnicos-científicos de evaluación y calificación de pérdida de capacidad laboral porcentual por sistemas ante una deficiencia, discapacidad y minusvalía que havan generado secuelas como consecuencia de una enfermedad o accidente." (Subrayas, negrilla y mayor tamaño de fuente fuera del texto original.)

La modificación planteada por este artículo representa un avance importante en la solución de problema, pues impone la obligación de efectuar la calificación de manera integral, pero a la vez aclara que debe hacerse especificando los porcentajes de pérdida de capacidad laboral por sistemas, es decir, que a la hora de emitir la calificación, el análisis de la misma debe discriminarse por sistemas, es decir, indicando qué porcentaje de disminución de capacidad laboral es atribuible a un riesgo común (caso en el cual lo asumirían, en principio, los sistemas de salud y/o pensiones) y qué porcentaje será atribuible a un riesgo laboral (caso en el cual lo asumiría, en principio, el sistema de riesgos laborales).

No obstante, la norma se queda corta pues no establece la necesidad de vincular al procedimiento de calificación a los diversos actores que pueden verse comprometidos en caso de establecerse una condición de invalidez compuesta por porcentajes de pérdida de capacidad laboral de distintos orígenes. Consideramos ineludible tal vinculación, pues de lo contrario se estaría violando el debido proceso y el derecho de contradicción de los eventuales obligados a asumir el pago de la pensión de invalidez, debiéndoseles garantizar la posibilidad de aportar su respectiva ponencia previa al dictamen y una vez emitido éste, notificárselos y darles la oportunidad de controvertirlo ante la Junta Nacional cuando sea el caso.

Como también se planteó, el artículo 2.2.5.1.50. del Decreto Único Reglamentario del Sector trabajo 1072 de 2015, en el cual se compilan los decretos que organizan y reglamentan el funcionamiento de las Juntas de Calificación de Invalidez, retoma el concepto de "calificación integral" y ordena que las solicitudes que lleguen a las Juntas provenientes de las entidades del sistema de seguridad social que asuman el riesgo de invalidez y muerte, “deben contener la calificación integral para la invalidez de conformidad la sentencia C-425 de 2005 de la Honorable Corte Constitucional y su precedente jurisprudencial. 
esto mismo aplicará para el correspondiente dictamen por parte de las Juntas de Calificación de Invalidez, Regional o Nacional.” (Subraya, negrilla y mayor tamaño de fuente fuera de texto original).

Esta norma también tiene en cuenta los efectos de la sentencia C-425 de 2005, extendiendo la obligación de calificación integral a las solicitudes de calificación que provengan de las entidades administradoras del sistema y dirigidas a la Junta Regional respectiva o a la Junta Nacional si es del caso, lo que implica un avance en la solución del problema, pues se está imponiendo a cargo de cada administradora el análisis de una posible concurrencia de calificaciones de diversos orígenes en cada caso concreto, lo que se traduce en la posibilidad de que desde el principio de la calificación se contemple la eventual acumulación de pérdidas de capacidad laboral. Sin embargo, consideramos que la norma sigue siendo etérea al no contemplar dentro del procedimiento de calificación, la obligación clara y expresa a cargo de la respectiva Junta de vincular al respectivo proceso a todas las entidades administradoras que puedan ver comprometida su responsabilidad a la hora de pagar una pensión de invalidez originada en la acumulación de riesgos comunes y laborales.

En la hora actual, la posición de las Cortes sigue siendo la planteada y por tanto, el problema sigue sin solución jurídica clara, viéndose como son cada vez más comunes los casos en los que por vía de una calificación integral, se establecen porcentajes de pérdida de capacidad laboral iguales o superiores al $50 \%$ pero compuestos por orígenes distintos, unos comunes y otros estrictamente laborales, lo que implica que en muchos de estos casos se termina condenando por vía judicial al asegurador que primero resulta vinculado en el proceso de calificación, dejando por fuera al otro eventual responsable, lo que denota un desequilibrio económico y procesal que no admite nuestro ordenamiento jurídico.

Como si fuera poco, el asegurador que resulta condenado se ve en serias dificultades para lograr el reembolso o el recobro de las sumas de las que debe disponer para pagar la pensión de invalidez que le fue impuesta, a cargo del asegurador que no fue condenado, pues normativamente no existe un fundamento claro que le permita lograr tal propósito.

De igual manera, se resaltan una serie de fenómenos que pueden hacer aún más dificultosa la solución del conflicto, como se puede dar en 
el caso de que uno de los riesgos que se concretaron y se reflejan en el porcentaje de pérdida de capacidad laboral, no haya estado cubierto por un asegurador, implicando que pudiere tenerlo que asumir el empleador que no afilió a la seguridad social a su trabajador durante ese determinado período en el que se realizó el riesgo o peor aún, que tuviere que asumirlo el propio trabajador si para ese momento en que se concretó su PCL, no hubiese estado vinculado laboralmente.

También puede ser materia de conflicto para el asegurador del Sistema de Pensiones en el Régimen de Ahorro Individual con Solidaridad, la posibilidad de que en caso de ser condenado a pagar de manera integral una pensión de invalidez con un componente de pérdida de capacidad laboral con origen laboral, no pueda hacer efectivo el seguro previsional tomado con la respectiva compañía de seguros para garantizar el cubrimiento de la suma restante que garantiza el pago vitalicio de la pensión, en tanto ésta puede oponerle la exclusión que le permite plantear la Resolución 530 de 1994 de la entonces Superintendencia Bancaria, en su artículo $2^{\circ}$ numeral $3^{\circ}$ "Exclusiones: la entidad aseguradora podrá excluir su responsabilidad solamente en los siguientes eventos: ... la invalidez o muerte originadas en accidente de trabajo o enfermedad profesional, no constituyen objeto de cobertura bajo este seguro".

Son estos solamente algunos ejemplos de los problemas que puede generar el efecto de la sentencia C-425 de 2005 y las posiciones afines que han venido reiterando la jurisprudencia constitucional y laboral, lo que impone a la mayor brevedad, la propuesta de posibles soluciones, que consideramos, deben ser de carácter normativo, resaltándose que no se han aprovechado escenarios para tales efectos como pudo ser la reforma del Sistema de Riesgos Laborales dispuesta en la Ley 1562 de 2012, momento para el cual ya estaba planteada la controversia.

\section{CONCLUSIONES}

- El estado actual de la jurisprudencia nacional en materia de acumulación de porcentajes de pérdida de capacidad laboral de diversos orígenes, permite la sumatoria indistinta de estos para lograr una condición material de invalidez y el respectivo pago de la pensión que ésta origina.

- Esta línea jurisprudencial se ve reflejada tanto en sentencias de la Corte Constitucional como de la Sala de Casación Laboral de la 
Corte Suprema de Justicia, en fallos como C-425 de 2005, T-518 de 2011 (Corte Constitucional) y 37.892 del 24 de julio de 2012 y 38.614 del 26 de junio de 2012.

- El estado actual de la jurisprudencia nacional no contiene criterios jurídicos claros que permitan establecer con precisión la entidad aseguradora del sistema de seguridad social que deba asumir el pago de la pensión de invalidez generada por acumulación de pérdidas de capacidad laboral de diversos orígenes.

- En las sentencias analizadas de la Sala de Casación Laboral de la Corte Suprema de Justicia se ha asignado la obligación de pagar de manera total a Administradoras de Riesgos Laborales, pensiones de invalidez que se derivan de pérdidas de capacidad laboral compuestas tanto por origen común como por origen laboral.

- Las claras diferencias que existen entre los Sistemas de Pensiones y Riesgos Laborales en el aseguramiento del riesgo de invalidez, impiden que se asigne indistintamente a uno u otro la asunción del pago total de una pensión de invalidez compuesta por orígenes de pérdida de capacidad laboral mixtos.

- La imposición de pago integral de pensiones de invalidez a cargo de un determinado asegurador del Sistema de Seguridad Social, bien sea en pensiones, bien sea en riesgos laborales, derivadas de la sumatoria de pérdidas de capacidad laboral de diversos orígenes, En las sentencias analizadas de la Sala de Casación Laboral de la Corte Suprema de Justicia se ha asignado la obligación de pagar de manera total a Administradoras de Riesgos Laborales, pensiones de invalidez que se derivan de pérdidas de capacidad laboral compuestas tanto por origen común como por origen laboral.

- En la legislación colombiana vigente no existe una solución expresa del problema, pues ante la declaratoria de inexequibilidad del parágrafo primero del artículo primero de la Ley 776 de 2002 por parte de la sentencia C-425 de 2005, no se ha expedido ninguna norma que permita establecer un procedimiento que garantice el derecho de defensa y contradicción tanto de los afiliados como de los aseguradores que potencialmente pueden verse avocados a asumir el pago integral de la pensión de invalidez.

- La Ley 1562 de 2012 que reformó el Sistema General de Riesgos Laborales, en su artículo 18 adicionó un inciso al artículo 41 de la Ley 100 de 1993, a su vez modificado por el artículo 142 del Decre- 
to 019 de 2012, que estableció la obligación de efectuarse una calificación por sistemas, es decir, estableciendo de manera discriminada los porcentajes de pérdida de capacidad laboral y sus respectivos orígenes, cuando se conjugan tanto como comunes como laborales. Sin embargo, dicha norma no soluciona el problema, pues no impone la necesidad de vincular al procedimiento de calificación a los diversos actores que pueden verse comprometidos en caso de establecerse una condición de invalidez compuesta por porcentajes de pérdida de capacidad laboral de distintos orígenes. Consideramos ineludible tal vinculación, pues de lo contrario se estaría violando el debido proceso y el derecho de contradicción de los eventuales obligados a asumir el pago de la pensión de invalidez, debiéndoseles garantizar la posibilidad de aportar su respectiva ponencia previa al dictamen y una vez emitido éste, notificárselos y darles la oportunidad de controvertirlo ante la Junta Nacional cuando sea el caso.

- El artículo 2.2.5.1.50 del Decreto 1072 de 2015, que incorporó el artículo 51 de Decreto 1352 de 2013 por el cual se organiza y reglamenta el funcionamiento de las Juntas de Calificación de Invalidez, retoma el concepto de "calificación integral" y ordena que las solicitudes que lleguen a las Juntas provenientes de las entidades del sistema de seguridad social que asuman el riesgo de invalidez y muerte, "deben contener la calificación integral para la invalidez de conformidad la sentencia C-425 de 2005 de la Honorable Corte Constitucional y su precedente jurisprudencial, esto mismo aplicará para el correspondiente dictamen por parte de las Juntas de Calificación de Invalidez Regional o Nacional." Esta norma también tiene en cuenta los efectos de la sentencia C-425 de 2005, extendiendo la obligación de calificación integral a las solicitudes de calificación que provengan de las entidades administradoras del sistema y dirigidas a la Junta Regional respectiva o a la Junta Nacional si es del caso, lo que implica un avance en la solución del problema, pues se está imponiendo a cargo de cada administradora el análisis de una posible concurrencia de calificaciones de diversos orígenes en cada caso concreto, lo que se traduce en la posibilidad de que desde el principio de la calificación se contemple la eventual acumulación de pérdidas de capacidad laboral. Sin embargo, consideramos que la norma sigue estando incompleta al no contemplar dentro del procedimiento de calificación, la obligación clara y expresa a cargo 
de la respectiva Junta de vincular al respectivo proceso a todas las entidades administradoras que puedan ver comprometida su responsabilidad a la hora de pagar una pensión de invalidez originada en la acumulación de riesgos comunes y laborales.

- Las posibles soluciones al conflicto jurídico planteado por la sentencia C-425 de 2005 deben tener en cuenta los siguientes aspectos:

- Se debe hacer por vía normativa de carácter legal en su sentido formal, es decir, como Ley expedida por el Congreso de la República, pues estará directamente relacionada con las prestaciones económicas que contempla el Sistema de Seguridad Social ${ }^{5}$.

- Debe modificarse el procedimiento actual de calificación de invalidez, disponiendo de manera expresa la obligación para la entidad calificadora que cuando encuentre que confluyen en su calificación porcentajes de pérdida de capacidad laboral de distintos orígenes, de vincular al procedimiento a las entidades aseguradoras del sistema eventualmente responsables e incluso a los empleadores (en caso que haya habido períodos sin cobertura del sistema), para que acudan a ejercer su derecho de contradicción y defensa.

- Se debe legislar señalando de manera expresa la forma como cada entidad aseguradora podrá ejercer su derecho de defensa ante la entidad calificadora, de tal manera que pueda exponer por vía de ponencia que será tenida en cuenta al momento de expedir la calificación, los argumentos de hecho y de derecho por los cuales considera que no está a su cargo la asunción de una parte de la prestación económica que pudiere generarse como consecuencia de los resultados del dictamen.

- Se debe legislar señalando de manera clara, precisa e inequívoca, los criterios por medio de los cuales se establecerá la distribución de la asunción del riesgo por parte de cada entidad aseguradora del respectivo sistema de pensiones o riesgos laborales en caso de concurrir porcentajes de pérdida de capacidad laboral de diversos orígenes.

5 Recuérdese que todo el articulado que contemplaba las prestaciones económicas del Sistema de Riesgos Profesionales en el Decreto 1295 de 1994, fue declarado inexequible por la sentencia C-452 de 2002 de la Corte Constitucional al considerar que el Ejecutivo se excedió en el uso de las facultades que al respecto le concedió la Ley 100 de 1993. 
- Se sugiere que se tengan en cuenta aspectos tales como:

- En materia de cubrimiento de riesgos laborales se sugiere mantener el sistema de distribución de riesgos entre las ARL contemplado en el artículo $1^{\circ}$ de la Ley 776 de 2002, donde se diferencia la cobertura de las prestaciones derivadas de un accidente de trabajo y las de una enfermedad laboral. De esta manera se garantiza que si confluyen diversos porcentajes de pérdida de capacidad laboral derivados de varios eventos laborales y, por ejemplo, uno de origen común, se distribuyan estos de manera proporcional en relación al porcentaje de PCL de cada uno, asumiéndose en dicha proporción la prestación a pagar entre la(s) ARL y el Fondo de Pensiones.

- El riesgo de invalidez asumido por los Fondos de Pensiones, por su parte, debe también corresponder en proporción al porcentaje de pérdida de capacidad laboral derivado de tal origen común.

- Se debe solucionar un obstáculo propio y exclusivo del aseguramiento del riesgo de invalidez del Sistema de Pensiones, cual es la ausencia del requisito del número de semanas cotizadas con anterioridad a la fecha de estructuración de la enfermedad o de ocurrencia del accidente común (art. 39 Ley 100 de 1993, modificado por el artículo $1^{\circ}$ de la Ley 860 de 2003).

- También se debe solucionar otro problema exclusivo del aseguramiento del riesgo de invalidez de origen común en el RAICS, en relación con el seguro previsional que toma la respectiva AFP para el cubrimiento del monto faltante para garantizar el pago vitalicio de la pensión, de tal manera que la aseguradora respectiva no pueda oponer la exclusión que contempla la Resolución 530 de 1994 de la Superintendencia Financiera, pues la aseguradora también estará indemnizando a la AFP en proporción al riesgo que ésta asumió y que corresponde con el monto de la prestación que deberá pagar.

- Se propone como posible solución a los dos problemas planteados en párrafos precedentes, acudir al seguro previsional de tal manera que cubra a favor del AFP las sumas faltantes del capital necesario para la pensión con el consecuente incremento de la prima, debido a que claramente se estaría 
incrementando el riesgo que estarían asumiendo las aseguradoras que explotan dicho ramo.

- Se debe legislar de tal manera que se establezca un claro sistema de recobros y reembolsos entre aseguradoras de ambos sistemas, pues le asiste razón a la Sala de Casación Laboral de la Corte cuando indica que sería contrario a los principios del sistema imponerle al trabajador un pago fraccionado de la mesada. De esta manera se asignaría el pago total de la pensión al asegurador del riesgo que mayor porcentaje de pérdida de capacidad laboral esté aportando, pero se le señalará la forma en que podrá recobrar dicho pago al otro u otros aseguradores involucrados.

- En los procesos judiciales en curso y que se sigan presentando mientras se legisla sobre la materia, se recomienda vincular por vía de llamamiento en garantía, denuncia del pleito o integración del contradictorio a la (las) entidad(es) aseguradora(s) que tuviesen a su cargo el cubrimiento del riesgo respectivo que pudiesen llegar a ser responsables parciales del pago de la prestación económica de pensión de invalidez. Con ello se garantiza el derecho de defensa de todas las partes del conflicto y se podría establecer en la sentencia la forma de asunción del riesgo proporcional a cargo de cada asegurador.

\section{BIBLIOGRAFÍA}

Cortés González, Juan Carlos. Régimen de los riesgos laborales en Colombia. Editorial Legis S.A. Bogotá, 2012, primera edición, págs. 267 y ss.

\section{Referencias Jurisprudenciales}

Corte Constitucional, Sala Plena. (26 de abril de 2005) Sentencia C-425. [MP Jaime Araújo Rentería]

Corte Constitucional, Sala Cuarta de Revisión. (5 de julio de 2011). Sentencia T-518. [MP Gabriel Eduardo Mendoza Martelo]

Corte Suprema de Justicia, Sala de Casación Laboral. (26 de junio de 2012) Sentencia expediente 38614. [MP Luis Gabriel Miranda Buelvas]

Corte Suprema de Justicia, Sala de Casación Laboral. (24 de julio de 2012) Sentencia expediente 37892. [MP Rigoberto Echeverri Bueno] 